\section{Adjudication in South African construction industry practice: towards legislative intervention}

M J Maritz, V Hattingh

Adjudication in South African construction practice has, through various initiatives of the South African government and Construction Industry Development Board, the increased use of international standard form construction contracts, and the South African High Court's robust approach in enforcing adjudicators' decisions, become relatively commonplace in both the public and private sectors as the first tier in dispute resolution procedures on construction projects across the South African construction industry.

This paper considers several judgements of the South African courts dealing with adjudication and certain of the South African government and Construction Industry Development Board's initiatives which, together with South African construction industry adjudication practice, combine in solidifying a foundation for the implementation of a legislative framework underpinning the application and practice of adjudication in the South African construction industry.

\section{INTRODUCTION}

"It certainly seems that construction contracts go wrong; everybody knows that. It is one of the problems of construction. The problems have intrigued, one might say obsessed, the industry and government for 50 years." (Fenn 2002).

Since 1995 the post-apartheid South African government has similarly been obsessed with the pursuit of procurement reform, especially in introducing appropriate methods for effective dispute resolution into the construction industry. Recognising the entrenchment of alternative dispute resolution (ADR) procedures for resolving labour disputes in the Labour Relations Act No 66 of $1995^{1}$ and successful application of ADR procedures in the private sector, the White Paper on Creating an Environment for Reconstruction Growth and Development in the Construction Industry commits the public sector to promoting the application of ADR procedures, in particular adjudication, in the South African construction industry. ${ }^{2}$

In promoting adjudication as the first tier in managing disputes throughout the South African construction industry, the White Paper confirms that "... recommendations adapted largely from the Latham report will be introduced to the construction industry, specifically for public-sector contracts." 3 Latham (1993), among other matters, “... recommended that a system of adjudication should be introduced within all the Standard Forms of Contract (except where comparable arrangements already exist for mediation or conciliation) and that this should be underpinned by legislation."

\section{ADJUDICATION IN SOUTH AFRICAN CONSTRUCTION INDUSTRY PRACTICE}

Adjudication has long been part of the panoply of ADR procedures available to parties bound by construction contracts, but until recent years was far from universal, and if the case law that refers to it is anything to go by, was not greatly used. Where adopted by the parties it was by express agreement in writing and contained an ad hoc set of rules that differed from contract to contract (Gaitskell 2011).

In addition to the South African government's interventions in promoting adjudication in South African construction practice, the industry itself has largely embraced the procedure "... whereby the parties agree to confer jurisdiction on an adjudicator to decide the particular dispute that has arisen between them ..." (Coulson 2007) as a means "... to find some sensible resolution of their problem and then get back to their real business ..." (Jackson 2006). As a matter of practice in the South African construction industry, the obligation to adjudicate, however, only arises consequent on a specific agreement to adjudicate, which agreement is recorded in the dispute management mechanisms captured in the particular construction contract.

Contractual adjudication has for some time now found a place in standard form

\section{JOURNAL OF THE SOUTH AFRICAN INSTITUTION OF CIVIL ENGINEERING}

Vol 57 No 2, June 2015, Pages 45-49, Paper 1042

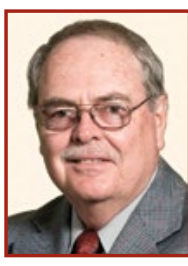

PROF TINUS MARITZ Pr QS obtained the degrees BSC (QS) and MSC (QS), both with distinction, in 1973 and 1987 respectively, and a $\mathrm{PhD}$ in 2003, all from the University of Pretoria. He is the author/co-author of various model documents for the South African building industry and has served on several governing bodies and technical committees, such as the South African Council for the Quantity Surveying Profession (SACQSP) and the Joint Building Contracts Committee (JBCC). He was appointed as fulltime lecturer in 1975 by the University of Pretoria, and is presently the head of the Department of Construction Economics and chairperson of the School for the Built Environment at the university.

Contact details:

Department of Construction Economics

Building 5 South Campus

University of Pretoria

Pretoria 0002

South Africa

T: $+27(0) 124204972$

E: tinus.maritz@up.ac.za

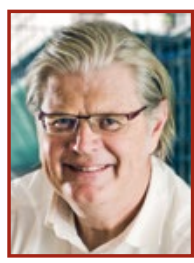

VAUGHAN HATTINGH [BA, LLB (Wits), PG Cert Construction Adjudication (Kings College, London), MSc in Construction Law and Dispute Resolution (Kings College, London)] is a qualified attorney and director of MDA Consulting (Pty) Ltd. In providing commercial and legal advisory services to both the South African and international construction industries for the past 15 years, Vaughan has been involved across all levels of the implementation of the adjudication process. Together with Prof M J Martiz (Head of Department of Construction Economics, University of Pretoria) he developed the Certificate Programme in Construction Adjudication currently presented by the Centre for Continuing Education at the University of Pretoria.

Contact details:

MDA Consulting (Pty) Ltd

111 Eckstein Street

Observatory

Johannesburg 2198

South Africa

T: +27 (0)11 6489500

E:vhattingh@mdaconsulting.co.za 
building contracts in use in South Africa, such as the Joint Building Contracts Committee's (JBCC) Principal Building Agreement (JBCC 2014) and the General Conditions of Contract for Construction Works (SAICE 2010), into which the adjudication process was introduced for the first time in 2004. A thorough knowledge of adjudication procedures and practice and implementation has now become essential for any construction professional playing a certifying, advisory or commercial role in a construction project.

Bvumbwe and Thwala (2011) conducted a study to determine which of the spectrum of ADR procedures (including specifically mediation and adjudication) are most frequently deployed through the South African construction industry in resolving construction disputes. They concluded that, although "... mediation is the most frequently used method in resolving disputes in the construction industry ... the majority of respondents would prefer the inclusion of adjudication as the priority in resolving a dispute before arbitration."

Van der Merwe (2009) conducted a comparative study of the application of both mediation and adjudication across the South African construction industry to determine which of the two dispute resolution methods is better suited to resolve construction disputes in this industry. In concluding that adjudication is preferable, Van der Merwe states "... that both mediation and adjudication are effective alternative methods of dispute resolution as to litigation and arbitration. Although adjudication has a weakness in the enforceability of the decision of the Adjudicator, it still has an advantage over mediation."

Maritz (2007) overviewed the development of adjudication in the South African construction industry, considering its effectiveness in resolving construction disputes, and the extent to which adjudication has been utilised since its introduction into this industry, and concludes that "... experience in other countries who have introduced adjudication has shown that adjudication without the statutory force is not likely to be effective. Enforcement of the adjudicator's decision is critical to the success of adjudication, and before South Africa introduces an Act similar to Acts such as the Housing Grants, Construction and Regeneration Act 1996 (UK), the Construction Contracts Act 2002 (NZ) or Building and Construction Industry Security of Payment Act 2004 (Singapore), adjudication will remain largely ineffective and, therefore, underutilised in the South African context."
Gaitskil (2007), echoing Maritz's observations, argues that “... in order for adjudication to have any real impact, it had to be compulsory so that powerful employers or main contractors could not simply strike such clauses out of contracts they made. This meant that there had to be legislation which simply imposed adjudication on all parties in the construction industry."

Following an investigation into adjudication practice in the South African construction industry, Maiketso and Maritz (2009) concluded "... that adjudication has found acceptance in the South African construction industry. However, it still has some way to go before its potential can be realised in full. Certain challenges need to be overcome to enable this to happen, which range from the contractual, institutional and legislative framework, to matters of skills and training."

\section{THE SOUTH AFRICAN HIGH COURT'S INTERVENTION IN ADJUDICATION PRACTICE}

Maritz (2007) correctly observes that “... enforcement of the adjudicator's decision is critical to the success of adjudication." In the United Kingdom (UK) neither the Housing Grants, Construction and Regeneration Act (HGCRA) nor the Scheme for Construction Contracts (the "Scheme") (enacted under the HGCRA) entrenches a procedure for enforcing adjudicators' decisions. The HGCRA simply provides that adjudicators' decisions are binding unless and until overturned by agreement, arbitration or litigation. Paragraph 23 (2) of the Scheme similarly provides that the decision is binding, pending final resolution by agreement, arbitration or litigation ${ }^{4}$. The absence of an enforcement mechanism entrenched in the legislation itself was initially perceived as a critical flaw in the legislation. Fortunately the English courts have consistently adopted a robust approach in enforcing adjudicators' decisions ${ }^{5}$ made through the statutorily regulated adjudication procedure ensuring that Parliament's intention in introducing the legislation is not thwarted.

In both Basil Read (Pty) Ltd $v$ Regent Devco (Pty) Ltd 6 and Freeman, August Wilhelm NO, Mathebula, Trihani Sitos de Sitos NO v Eskom Holdings Limited ${ }^{7}$ the High Court of South Africa has exhibited a clear willingness to adopt a similarly robust approach to enforcement of adjudicators' decisions.

The South African High Court's initial willingness to adopt such a robust approach to the enforcement of adjudicators' decisions has been reinforced through two recent decisions in the High Court of South Africa, namely: in an unreported judgement of the South Gauteng High Court on 3 May 2013 handed down by D T v R du Plessis A J in Tubular Holdings (Pty) Ltd $v$ DBT Technologies (Pty) $L t d^{8}$, and in another unreported judgement of the South Gauteng High Court handed down by Spilg J on 12 February 2013 in Esor Africa (Pty) Ltd / Franki Africa (Pty) Ltd JV v Bombela Civils JV9.

In Tubular Holdings (Pty) Ltd $v$ DBT Technologies (Pty) Ltd several disputes arising in connection with a subcontract between Tubular Holdings and DBT Technologies on the Kusile coal-fired power station project had been referred to a Dispute Adjudication Board (DAB) consisting of a single member who had furnished a decision on the disputes referred. Tubular Holdings thereafter made application to the South Gauteng High Court by motion application for an order compelling DBT Technologies to comply with the DAB's decision.

The kernel of the issue between the parties before Du Plessis A J related to the interpretation of the standard clause 20.4 of the FIDIC Conditions of Contract 1999, First Edition (FIDIC 1999). Du Plessis A J summarised the dispute as follows at paragraph [5]: "The applicant submits that the parties are required to give prompt effect to the decision by the DAB which is binding unless and until it is set aside by agreement or arbitration following a notice of dissatisfaction whereas the respondent says that the mere giving of a notice of dissatisfaction undoes the effect of the decision."

In granting Tubular Holdings an order for specific performance compelling DBT Technologies to comply with the DAB's decision Du Plessis A J, specifically in regard to clause 20.4 of the FIDIC 1999, held at paragraph [14] that "[T]he scheme of these provisions is as follows: the parties must give prompt effect to a decision. If a party is dissatisfied he must nonetheless live with it but must deliver his notice of dissatisfaction within 28 days failing which it will become final and binding. If he has given his notice of dissatisfaction he can have the decision reviewed in arbitration. If he is successful the decision will be set aside. But until that has happened the decision stands and he has to comply with it."

In Esor Africa (Pty) Ltd / Franki Africa (Pty) Ltd JV v Bombela Civils JV a dispute arose in connection with certain construction works executed by Esor Africa / Franki Africa JV relating to certain piling and lateral support work on the Gautrain rapid rail link project. The dispute referred to a $\mathrm{DAB}$ also consisting of a single member in accordance with clause 20.4 of the FIDIC 
1999. The DAB had furnished a decision on the dispute referred. Esor Africa / Franki Africa JV thereafter made application for an order for specific performance compelling Bombela Civils JV to comply with the DAB's decision.

The dispute between the parties before Spilg J fell to be resolved by "a proper interpretation of the dispute resolution clauses dealing with the effect of a DAB decision" (refer to paragraph [7]).

In granting the Esor Africa / Franki Africa JV the order for specific performance Spilg J concluded at paragraph [13] that, "[I]n order to give effect to the DAB provisions of the contract the respondent cannot withhold payment of the amount determined by the adjudicator, and in my view is precluded by the terms of the provisions of clause 20 (and in particular clauses 20.4 and 20.6) from doing so pending the outcome of the arbitration. In my view it was precisely to avoid this situation that the clauses were worded in this fashion."

The High Court of South Africa's robust approach in enforcing adjudicators' decisions is succinctly summarised by Spilg J in Esor Africa / Franki Africa JVv Bombela Civils $J V$ at paragraph [15] as follows: "The court is required to give effect to the terms of the decision made by the adjudicator. The DAB's decision was not altered and accordingly it is that decision which this court enforces."

In Sasol Chemical Industries Ltd v Odell and another ${ }^{10}$ (the first South African court case dealing with an application to set aside an adjudicator's determination as opposed to enforcement of an adjudicator's determination) Kruger J considered an urgent application by Sasol Chemical Industries Ltd (Sasol) to set aside an adjudicator's award on the basis that the adjudicator did not entertain a request by Sasol for an extension of time to furnish information. The adjudication had proceeded in accordance with the provisions of the New Engineering Contract, Third Edition (ICE 2005), Engineering Construction Contract Option W1. Sasol had failed to furnish information in response to E - Hel Services (Pty) Ltd's (the second respondent) submission within the strict time limits prescribed in clause W1.3 (3), and thereafter to conclude an agreement with E - Hel Civil Services and the adjudicator to extend the time limits. Sasol then applied to the adjudicator to grant an extension of time to the prescribed time limits within which to furnish information. The adjudicator refused to grant Sasol's request and proceeded to furnish his determination on 3 February 2014.

In refusing Sasol's application to set the adjudicator's determination aside
Kruger J confirmed the High Court's robust approach holding that "[A]djudication is meant to be a speedy remedy to assist cash flow and not to hold up the contract. The finding of the adjudicator stands until it is set aside by the tribunal. The remedy of the applicant is to place its case before the tribunal. Even if in this case the adjudicator may have made a mistake by not entertaining the request of the applicant for an extension of time (and I do not think the adjudicator made a mistake) the adjudication stands." 11

In Radon Projects $v N$ V Properties ${ }^{12}$ the South African Supreme Court of Appeal considered the court a qou's order that an appointed arbitrator had no jurisdiction to arbitrate the referred dispute, as the dispute had arisen prior to practical completion and was as such required to be submitted to adjudication in the first instance, in accordance with clause 40 of the Fourth Edition of JBCC (JBCC 2004). ${ }^{13}$

In reversing the court a quo's decision Nugent J A (delivering a unanimous judgement) squarely confirmed adjudication's place in South African construction dispute management practice, concluding that "[W]hen read together with the Rules, I think it is plain that, in keeping with modern practice internationally, adjudication under clause 40 is designed as a measure for the summary and interim resolution of disputes, subject to their final resolution by arbitration where appropriate." ${ }^{14}$

The South African Courts' consistent willingness to adopt a robust approach to enforcing adjudicators' decisions has contributed significantly toward securing the increasing adoption of adjudication into South African jurisprudence and construction practice as a first tier dispute management procedure and the development of a solid foundation for a legislative framework to underpin the procedure.

\section{THE CIDB DRAFT PROMPT PAYMENT AND ADJUDICATION REGULATIONS}

A form of statutory adjudication has already found a seat in South African legislation through Part F (Companies Tribunal adjudication procedures) of the Companies Act ${ }^{15}$ which provides opportunity to parties (as opposed to a statutory obligation ${ }^{16}$ ) to refer disputes arising under or in connection with the application of the Companies Act to a public authority known as the Companies Tribunal for resolution. The Companies Tribunal is specifically prescribed when adjudicating referred disputes to “... conduct its adjudication proceedings contemplated in this Act expeditiously in accordance with the principles of natural justice"17 and ... "may conduct those proceedings informally ..."18

Statutory adjudication is, consequent to the enactment of Part F (Companies Tribunal adjudication procedures) of the Companies Act ${ }^{19}$, no longer entirely foreign to South African jurisprudence - both the South African government and construction industry have recognised the proven effectiveness of such systems internationally, and the South African courts have exhibited a definite willingness to enforce an adjudicator's decision.

Statutory adjudication was first introduced into the UK through enactment of Part II of the HGCRA which came into force in May 1998. The Local Democracy Economic Development Act, 2009 subsequently effected changes to the adjudication and payment provisions contained in the HGCRA.

Three years after enactment of the HGCRA the state of New South Wales enacted the Building and Construction Industry Security of Payment Act, 1999 (the NSW Act), modelled on the HGCRA. The NSW Act served as the model upon which most other Australian jurisdictions, to varying degrees, based their construction contracts legislation, culminating in the Tasmanian Act which received Royal Assent on 17 December 2009. Other states and territories across Australia, including Victoria ${ }^{20}$, Queensland ${ }^{21}$, Northern Territory ${ }^{22}$, Western Australia ${ }^{23}$, Australian Capital Territory ${ }^{24}$, South Australia ${ }^{25}$ and Tasmania ${ }^{26}$, have each enacted security of payment legislation. Similar legislation has subsequently been enacted in several jurisdictions, including (among other jurisdictions) Singapore ${ }^{27}$, and most recently Malaysia $^{28}$.

The CIDB has made a concerted effort to overcome the challenges referred to by Maiketso and Maritz (2009), and by initiating the procedure stipulated in section 33 (Regulations) of the CIDB Act 38 of 2000 the CIDB is building upon the foundations for such legislative intervention being laid through the South African Court intervention and industry adjudication practice.

An internal task team was set up for this purpose by the Director General of the Department of Public Works. The work of the task team in preparing a revised set of draft regulations is now concluded. The draft regulations consist of Part IV C titled "Prompt Payment" and Part IV D titled "Adjudication" (the "draft regulations") including a Standard for Adjudication (the "Standard"). Although the CIDB Board has not approved the final revised set of draft regulations, they approved the process at this 
stage. Once the regulations have been finalised after the mandatory public comment phase, they shall be submitted to the Board for final approval.

By application of sub-paragraph (1) of regulation $26 \mathrm{P}$ (Right to refer disputes to adjudication) of Part IV D (Adjudication) a mandatory form of statutory adjudication will be introduced into the South African construction practice. Sub-paragraph (1) of regulation $26 \mathrm{P}$ (Right to refer disputes to adjudication) of Part IV D (Adjudication) provides:

(1) Every construction works, or construction works-related contract, must provide for an adjudication procedure, which must substantially comply with these Regulations and if that contract does not contain such a procedure, or in the case of a verbal contract, the provisions of this Part and the Standard for Adjudication, apply to that contract.

Sub-paragraph (1) requires the parties to any written construction works or construction works-related contract to include an adjudication procedure into the contract.

In the event that the adjudication procedure provided for in the express terms of the contract does not substantially comply with these Regulations then by default the provisions of Part IV D (Adjudication) together with the "Standard" will apply automatically. Similarly, if the parties conclude any oral construction works contract or construction works-related contract then (in the absence of express terms recorded in writing) by default the provisions of Part IV D (Adjudication) together with the "Standard" will apply automatically.

\section{CONCLUSION}

The South African courts' robust approach to enforcing adjudicator's decisions, initiatives of both the South African government and CIDB particularly, coupled with the industry's persistent application of contractual adjudication procedures, are reinforcing a proper foundation upon which to implement a legislative framework to underpin adjudication practice in the South African construction industry.

The proposed legislative framework will (once implemented) solidify a desperately needed “... speedy mechanism for settling disputes in construction contracts on a provisional interim basis and requiring the decision of adjudicators to be enforced pending the final determination of disputes by arbitration, litigation or agreement ..."29 into South African jurisprudence and construction industry practice, therefore significantly contributing towards "... delivery, performance and value for money, profitability and the industry's long-term survival in an increasingly global arena ..."30

\section{NOTES}

1 The Labour Relations Act No 66 of 1995 was enacted to, inter alia, provide simple procedures for the resolution of labour disputes through statutory conciliation, mediation and arbitration (for which purpose the Commission for Conciliation, Mediation and Arbitration was established), and through independent ADR services accredited for that purpose.

2 The White Paper on Creating an Enabling Environment for Reconstruction, Growth and Development in the Construction Industry, published under Notice 89 in Government Gazette No 18615, Volume 391 on 14 January 1998.

3 Refer to note 2 above under paragraph 4.1.5.3 (ADR).

4. Section 108 (3) of the HGCRA, 1996.

5 See for example Balfour Beatty Construction Ltd $v$ the Mayor \& Burgess of the London Borough of Lambeth (2002) EWHC 597.

6 An unreported decision of the South Gauteng High Court handed down on 9 March 2010.

7 An unreported judgement of the South Gauteng High Court dated 23 April 2010.

8 An unreported judgement of the South Gauteng High Court dated 3 May 2013.

9 An unreported judgement of the South Gauteng High Court dated 12 February 2013.

10 Sasol Chemical Industries $v$ Odell and another, an unreported judgement of the Free State High Court, Bloemfontein dated 20 February 2014.

11 Refer to note 10 at paragraph 19.

12 Radon Projects $v N$ V Properties and Gary Stephen Myburgh (2013) 3 All SA 615 (SCA).

13 Clause 40 of the Fourth Edition, March 2004, of the JBCC Principal Building Agreement, which at clause 40.4 provides that "a dispute ... shall be submitted to ... [40.4.2] adjudication where practical completion .. has not been achieved."

14 Refer to note 12 at paragraph 8.

15 The Companies Act No 71 of 2008 has completely overhauled the South African company law legislative framework.

16 Section 181 (Right to participate in hearing) of the Companies Act No 71 of 2008.

17 Refer to note 15 above at Section 180 (Adjudication hearings before Tribunal) (1) (a).

18 Refer to note 15 above at Section 180 (Adjudication hearings before Tribunal) (1) (b).

19 Refer to note 15 above.

20 The Victoria Building and Construction Industry Security of Payment Act 2002 (amended in 2006).

21 The Queensland Building and Construction Industry Payments Act 2004.

22 The Northern Territory Construction Contracts Act 2004.

23 The Western Australia Construction Contracts Act 2004
24. The Australian Capital Territory Building and Construction Industry (Security of Payment) Act 2009.

25 The South Australia Building and Construction Industry Security of Payment Act 2009.

26 The Tasmanian Building and Construction Industry Security of Payment Act 2009.

27 The Building and Construction Industry Security of Payment Act 57 of 2004. The Security of Payment Regulations 2005 enacted by the Minister for National Development in terms of section 41 of the Act came into operation on 1 April 2005.

28 The Construction Industry Payment and Adjudication Act (CIPAA) 2012 was passed on 18 June 2012 and gazetted on 22 June 2012. The Ministry of Works had proposed the Construction Industry Payment and Adjudication (Exemption) Order 2014 and the amended Construction Industry Payment and Adjudication Regulations 2014. Both had been approved by the Minister of Works and became effective on 15 April 2014.

29 Justice Dyason in the landmark UK case of Macob Civil Engineering Ltd v Morris Construction Limited (1999) BLR 93 TCC at page 97.

30 Construction Industry Adjudication Procedure, March 2004, First Edition of CIDB document 1014, downloadable from www.cidb.org.za.

\section{REFERENCES}

Bvumbwe, C \& Thwala, D W 2011. An exploratory study of dispute resolution methods in the South African construction industry. IPEDR Vol 21, Singapore: IACSIT Press.

Coulson, R (Sir) 2007. Construction Adjudication, 1st ed. Oxford: Oxford University Press.

Fenn, P 2002. Why construction contracts go wrong? (or an aetiological approach to construction disputes). Paper presented at a meeting of the Society of Construction Law in Derbyshire, UK. Available at: http://www.scl.org.uk.

FIDIC (Fédération Internationale des IngénieursConseils - FIDIC International Federation of Consulting Engineers) 1999. Conditions of Contract for Construction: For Building and Engineering Works Designed by the Employer, 1st ed. Lausanne, Switzerland: FIDIC.

Gaitskell, R 2007. International statutory adjudication: Its development and impact. Construction Management and Economics, 25(7): 777-784.

Gaitskell, R 2011. Construction Dispute Resolution Handbook, 2nd ed. London: Institution of Civil Engineers (ICE, UK), p 75.

ICE (Institute of Civil Engineers, UK) 2005. New Engineering Contract, 3rd ed. NEC3, Glasgow, Scotland: ICE.

Jackson, R 2006. The Tower of Babel: What happens when a building contract goes wrong? 2006 Denning Lecture given in Gray's Inn, London. Available at: http://www.scl.org.uk.

JBCC (Joint Building Contracts Committee Inc) 2004. Principal Building Agreement (PBA), 4th ed. Code 2101. Johannesburg: JBCC. 
JBCC (Joint Building Contracts Committee Inc) 2014. Principal Building Agreement (PBA), 6.1th ed. Code 2101. Johannesburg: JBCC.

Latham, M 1993. Trust and money. Interim Report of the Joint Government/Industry Review of the Procuremen and Contractual Arrangements in the United Kingdom Construction Industry, London: HMSO.

Maiketso, N C \& Maritz, M J 2009. What are the requirements for the South African construction industry to fully utilise adjudication? Paper presented at the Royal Institute of Chartered Surveyors Conference, Dublin, Ireland.

Maritz, M J 2007. An investigation into the adjudication of disputes in the South African construction industry. Paper presented at the Royal Institute of Chartered Surveyors Conference, Kuala Lumpur, Malaysia.
SAICE (South African Institution of Civil Engineering) 2010. General Conditions of Contract for Construction Works, 2nd ed. Midrand: SAICE.

Van der Merwe, C J 2009. Is adjudication a better procedure for construction dispute resolution than mediation? MEng dissertation, Pretoria: Department of Construction Economics, University of Pretoria. 